\title{
Production and quality of Date fruit in response to pollination methods
}

\author{
Muhammad Mahmood-ur-Rahman Jamro ${ }^{1 *}$, Muzafar Hussain Sirohi², \\ Ameer Ahmed Mirbahar ${ }^{3}$, Sham $\mathrm{Lal}^{4}$ and Mumtaz Ali Saand ${ }^{5}$ \\ 1. PARC-AZRI Technology Field Station Khairpur, Sindh-Pakistan \\ 2. Department of Botany, Shah Abdul Latif University Khairpur-Pakistan \\ 3. Date Palm Research Institute (DPRI), Shah Abdul Latif University Khairpur-Pakistan \\ 4. Institute of Microbiology, Shah Abdul Latif University, Khairpur, Sindh-Pakistan \\ 5. Centre for Conservation and Biodiversity (CBC), Shah Abdul Latif University Khairpur-Pakistan \\ *Corresponding author's email: mrjamro@yahoo.com
}

Citation

Muhammad Mahmood-ur-Rahman Jamro, Muzafar Hussain Sirohi,Ameer Ahmed Mirbahar, Sham Lal and Mumtaz Ali Saand. Production and quality of Date fruit in response to pollination methods. Pure and Applied Biology.Vol. 9, Issue 3, pp1737-1742. http://dx.doi.org/10.19045/bspab.2020.90184

\begin{tabular}{llll}
\hline \hline Received: 10/01/2020 & Revised: 24/03/2020 & Accepted: 06/04/2020 & Online First: 12/04/2020 \\
\hline
\end{tabular}

\section{Abstract}

Date palm (Phoenix dactylifera L.) is the foremost fruit plant of Sindh, Pakistan. The plant is dioecious and requires artificial pollination. The mechanical devices are also introduced to save overall production cost and improved fruit yield. Therefore this study tested the effectiveness of both, manual and mechanical, pollination methods in selected date palm cultivars. In this regard, six date palm cultivars namely Aseel, Dhakki, Muzawati, Hussaini, Karbalain and Shakri were selected for both successive seasons 2017 and 2018 at Date Palm Research Station, Kotdiji, Khairpur (Mir's) Sindh, Pakistan. The selected date palm cultivars pollinated by manual and mechanical pollination methods. The study identified significant variations in fruit characters among the six cultivars. The cultivars Dhakki and Shakri produced relatively larger fruits compared to the rest of cultivars. These cultivars produced larger fruit pulp with average length $4.1 \mathrm{~cm}$ and diameter $2.3 \mathrm{~cm}$ when pollinated by manual method. Whereas, Flesh weight, seed weight, bunch weight and total yield of plants were not significantly different in manually and mechanically pollinated plants. Further, the experiments suggested optimizing the mechanical pollination method for better fruit quality and yield, using a varied concentration of pollen powder and frequency of pollination.

Keywords: Date palm; Fruit quality; Pollination methods; Yield

\section{Introduction}

Date Palm (Phoenix dactylifera L.) is one of the oldest fruit trees on the planet. It is known as "tree of life" for high nutritional value, productivity and long yield-life (more than 50 years). The tree grows better in a warm climate where summers are considerably longer than winters. Date palm belongs to Arecaceae family and is known as an icon of life in desert, because it is high tolerance to temperature and abiotic stresses [1]. It requires hot and rainless growing season for fruit production and ripening. Due to genetic differences and climatic conditions, fruit varies in softness, texture, size, weight, shape and color [2]. However, large number of varieties exists across the warm climatic regions of Sindh province. The predominant 
cultivars of region include Aseel, Karbalain, Eidal Shah, Kashuwari and Dhakki.

High potent pollen sources have direct effect on fruit setting, properties and production of Date palm [3, 4]. Many scientists reported that male pollens have key role on size and weight of fruit $[5,6,7]$. The pollen grains affects directly on the receptiveness of female bunch [8]. Date palm is a dioecious plant and requires a vector in pollination for successful reproduction and fruit quality [9]. Manual pollination (hand pollination) is customary method of date palm pollination among the farmers in which a few male strands placed lengthwise in an inverted position among the strands of female inflorescence [10]. This fruit croprequires substantial human efforts and labor cost to pollinate large number of Date palm trees in a short span of pollination period. On the other hand, various mechanical devices developed to assist in date palm pollination to reduce the cost and time. However, farmers are reluctant to adopt new methods of pollination in date palm partially due to indeterminate results. Therefore, this study reported the fruit characters and tested the potential of both, manual pollination (traditional) and mechanical (non-traditional) on various Date palm cultivars commonly grown in the region of Sindh Pakistan.

\section{Materials and methods}

The experiments were conducted at Date Palm Research Station, Kotdiji, Khairpur (Mir's), Sindh, Pakistan during seasons in 2017 and 2018. Six Datepalm cultivars namely Aseel, Dhakki, Muzawati, Hussaini, Karbalain and Shakri trees of age between 17 and 20 years selected. The experiments conducted with two treatments and three replications in Completely Randomized Design. The pollination was carried out from $3^{\text {rd }}$ to $06^{\text {th }}$ March 2017 and $5^{\text {th }}$ to $8^{\text {th }}$ March 2018 at 10:00 am.

In Manual method of pollination, male strands were separated and each female tree was pollinated manually by placing 3-4 strands length wise among the strands of female bunch. For Mechanical method, the pollen powder harvested from staminate inflorescence. The pollens sprayed on the opened spathes by a pollen Atomiser machine model-M-2010, Teeba Eng: industries, UAE. The machine has a capacity to pollinate more than 250 date palm tree in eight hours. The spathes covered with Tyvek bags to avoid contamination after pollination. Data recorded for fruit and yield parameters at maturity.

The data for fruit and yield parameters described in descriptive statistics and further analyzed for variation among the cultivars by computing Analysis of Variance [11]. A dendrogram was figured using centroid clustering method, computing the Squared Euclidean Distance among the cultivar based on fruit characteristics. Independent samples $t$-test was used to determine the significant mean difference in fruit quality and yield parameter in result of manual and mechanical pollination. The $t$-test results accepted after meeting the assumption of Homogeneity of variance using Levene's test [12].

\section{Results and discussion Effect of pollination methods on fruit and yield}

Total number of bunches in plant is a varietal character and varies among the cultivars. The cultivars produced more than twelve bunches. There was a significant difference in number of bunches produced by cultivars (Anova, $d f=5, f=4.5, p<0.01$ ), with cv. Karbalain having a significantly higher number of bunches (mean 16.2) than cvs. Hussaini, Shakri and Aseel (Table 1). The single fruit weight reflected with flesh and seed weight. In dates, the low seed (stone) weight is considered as quality character of fruit. Although, Anova revealed a significant difference in seed weight among the cultivars $(d f=5, f=3.7, p<0.01)$. The post hoc analysis disclosed significantly higher seed weight of 
cv. Shakri than cvs. Hussaini, Aseel, Muzawati and Karbalain (Table 1). In contrast, the flesh weight of a single fruit varied significantly among all cultivars (Anova, $d f=5, \quad f=166.7, \quad p<0.01$ ), consequently resulting in the variation of a single fruit weight among the cultivars (Anova, $d f=5, f=140.1, p<0.01$ ). Dhaki cv. produced a higher flesh weight in single fruit (Table 1)

Table1. Fruit characters of various date palm cultivars as affected by manual and mechanical pollination method

\begin{tabular}{|c|c|c|c|c|c|c|c|c|}
\hline $\begin{array}{c}\text { Name of } \\
\text { cultivar }\end{array}$ & $\begin{array}{c}\text { No. of } \\
\text { bunches } \\
\text { per plant }\end{array}$ & $\begin{array}{c}\text { Weight of } \\
\text { single } \\
\text { bunch } \\
(\mathbf{K g})\end{array}$ & $\begin{array}{c}\text { Single } \\
\text { fruit } \\
\text { weight } \\
(\mathbf{g})\end{array}$ & $\begin{array}{c}\text { Seed } \\
\text { weight } \\
(\mathbf{g})\end{array}$ & $\begin{array}{c}\text { Flesh } \\
\text { weight } \\
(\mathbf{g})\end{array}$ & $\begin{array}{c}\text { Fruit } \\
\text { length } \\
(\mathbf{c m})\end{array}$ & $\begin{array}{c}\text { Fruit } \\
\text { diamet } \\
\text { er } \\
(\mathbf{c m})\end{array}$ & $\begin{array}{c}\text { Yield per } \\
\text { plant } \\
(\mathbf{K g})\end{array}$ \\
\hline ASEEL & $\begin{array}{c}12.0 \\
(2.3)^{\mathrm{a}}\end{array}$ & $7.7(0.8)^{\mathrm{b}}$ & $6.9(0.7)^{\mathrm{c}}$ & $\begin{array}{c}0.8 \\
(0.1)^{\mathrm{a}}\end{array}$ & $\begin{array}{c}6.02 \\
(0.7)^{\mathrm{c}}\end{array}$ & $\begin{array}{c}3.8 \\
(0.2)^{\mathrm{bc}}\end{array}$ & $\begin{array}{c}2.2 \\
(0.3)^{\mathrm{abc}}\end{array}$ & $\begin{array}{c}94.8 \\
(12.7)^{\mathrm{c}}\end{array}$ \\
\hline DHAKKI & $\begin{array}{c}15.7 \\
(1.2)^{\mathrm{bc}}\end{array}$ & $10.8(0.8)^{\mathrm{c}}$ & $13.7(0.9)^{\mathrm{e}}$ & $\begin{array}{c}1.0 \\
(0.1)^{\mathrm{ab}}\end{array}$ & $12(0.9)^{\mathrm{e}}$ & $4.9(0.6)^{\mathrm{d}}$ & $\begin{array}{c}2.6 \\
(0.3)^{\mathrm{c}}\end{array}$ & $\begin{array}{c}139.0 \\
(4.2)^{\mathrm{e}}\end{array}$ \\
\hline $\begin{array}{c}\text { MUZAWAT } \\
\text { I }\end{array}$ & $\begin{array}{c}14.3 \\
(1.0)^{\mathrm{abc}}\end{array}$ & $6.8(1.2)^{\mathrm{ab}}$ & $5.8(0.6)^{\mathrm{b}}$ & $\begin{array}{c}0.9 \\
(0.1)^{\mathrm{a}}\end{array}$ & $4.9(0.5)^{\mathrm{b}}$ & $\begin{array}{c}3.4 \\
(0.4)^{\mathrm{ab}}\end{array}$ & $\begin{array}{c}1.9 \\
(0.2)^{\mathrm{ab}}\end{array}$ & $80.5(3.4)^{\mathrm{b}}$ \\
\hline HUSSAINI & $\begin{array}{c}12.6 \\
(1.2)^{\mathrm{a}}\end{array}$ & $6.0(0.6)^{\mathrm{a}}$ & $3.9(0.3)^{\mathrm{a}}$ & $\begin{array}{c}0.9 \\
(0.1)^{\mathrm{a}}\end{array}$ & $3.0(0.2)^{\mathrm{a}}$ & $3.3(0.4)^{\mathrm{a}}$ & $\begin{array}{c}1.9 \\
(0.2)^{\mathrm{a}}\end{array}$ & $71.2(4.1)^{\mathrm{a}}$ \\
\hline KARBALAI \\
\hline N & $\begin{array}{c}16.2 \\
(0.8)^{\mathrm{c}}\end{array}$ & $7.1(0.2)^{\mathrm{b}}$ & $8.5(0.6)^{\mathrm{d}}$ & $\begin{array}{c}0.8 \\
(0.1)^{\mathrm{a}}\end{array}$ & $7.6(0.6)^{\mathrm{d}}$ & $\begin{array}{c}3.5 \\
(0.5)^{\mathrm{abc}}\end{array}$ & $\begin{array}{c}2.2 \\
(0.3)^{\mathrm{abc}}\end{array}$ & $\begin{array}{c}106.8 \\
(6.6)^{\mathrm{d}}\end{array}$ \\
\hline SHAKRI & $\begin{array}{c}13.7 \\
(2.7)^{\mathrm{ab}}\end{array}$ & $11.0(0.9)^{\mathrm{c}}$ & $8.9(0.8)^{\mathrm{d}}$ & $\begin{array}{c}1.1 \\
(0.2)^{\mathrm{b}}\end{array}$ & $7.8(0.7)^{\mathrm{d}}$ & $4.0(0.4)^{\mathrm{c}}$ & $\begin{array}{c}2.2 \\
(0.3)^{\mathrm{bc}}\end{array}$ & $\begin{array}{c}114.0 \\
(1.8)^{\mathrm{d}}\end{array}$ \\
\hline
\end{tabular}

The data represent mean values and standard deviation in brackets. Superscripts letter represent the homogenous subsets analyzed in Duncan post hoc Test at significance level $\mathrm{p}=0.05$

Similarly, fruit length (Anova, $d f=5, f=12.2$, $p<0.01$ ) and diameter (Anova, $d f=5, f=4.4$, $p<0.01)$ was significantly different among the cultivars. Hussaini cv. produced fruit with comparatively lesser length and diameter (Table 1). In contrast the fruit of cv. Dhakki was large in size (Table 1). The weight of a single bunch $(d f=5, f=43.0, p<0.01)$ and total yield of the plant (Anova $d f=5, f=84.8$, $p<0.01$ ) also varied among the cultivars. Weight of the single bunch and yield per plant was significantly higher in cv. Dhakki and cv. Shakri than the rest of the cultivars (Table 1). Based on the overall fruit and yield characteristics, the clustering analysis revealed a higher resemblance among Muzawati, Hussaini and Aseel cultivars (Fig. 1). In contrast, Dhakki and Shakri found to be at higher distance from the rest of the cultivars in clustering analysis (Fig. 1). Our results indicate that Dhakki and Shakri cultivars produced better yield in agro- climatic conditions of Khairpur region. The total yield mean $139 \mathrm{~kg}$ of Dhakki cultivar was $45 \%$ higher than the total yield of same cultivar recorded in the agro-climatic conditions of Dera Ismail Khan [3]. Similarly, total yield of Shakri cultivar (mean $114 \mathrm{~kg} /$ plant) was more than double the recorded yield $(44.24 \mathrm{~kg})$ in Dera Ismail Khan Region [3]. In contrast, the same study has shown a higher weight of single fruit of Dhakki (21.59g) and Shakri (10.88g) cultivars [3]. The size and weight of single fruit, may increase due to lower number of fruits in the bunch. This can be improved through thinning procedure [13].

Pollen grains play a vital role in the fruit quality of Dates and therefore an effective method of pollination is equally important. We recorded slightly higher length of fruit $(t$ test (18) 2.8, $p<0.01)$ in the dates pollinated by Manual method (Mean=4.1, SD =0.6) as compared to Mechanical method $($ Mean = 
3.5, $\mathrm{SD}=0.6)$. Also, the diameter of fruit produced in Manual method (Mean=2.3, $\mathrm{SD}=0.3)$ was larger $(t$-test $(18) 0.43, p<0.01)$ than fruit produced mechanical method of pollination (Mean $=1.9, \mathrm{SD}=0.2$ ). The study did not find any significant difference in Flesh weight ( $t$-test (18) $0.45, p=0.6$,
Number of bunches per plant ( $t$-test (18) 0.07, $p=0.9)$, Seed weight $(t$-test (18) 1.9, $p=$ 0.58 ), Fruit weight ( $t$-test (18) $0.54, p=$ 0.59 ), Weight of bunch ( $t$-test (18) $0.21, p=$ 0.83 ), Yield of plant ( $t$-test (18) $0.091, p=$ $0.92)$ in relation with two pollination methods (Fig. 2).

\section{Rescaled Distance Cluster Combine}

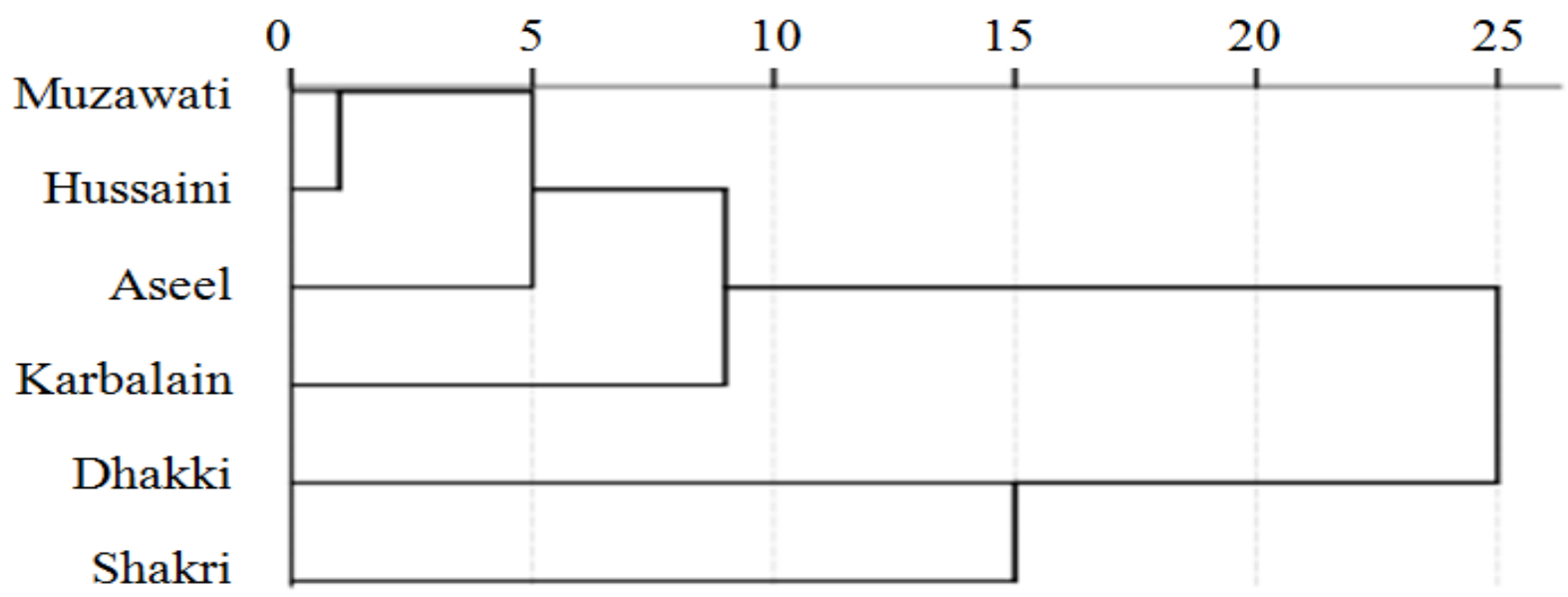

Figure 1. Dendrogram using centroid linkage, horizontal-axis showing the rescaled distance between the cultivars based on fruit and yield characters

The size of fruit considered as a quality character in Dates, this study found an improved quality fruit because of manual pollination method. Other studies have also reported a better fruit in hand pollinated dates. Higher length of fruit in cv. Sheshi reported with manual pollination method [14, 15]. On the contrary, the same study reported better quality fruit of $\mathrm{cv}$. Khalas with mechanical pollination method [15]. While [16] did not observed any effect of mechanical and manual pollination methods on fruit qualities of Dates.

The effect of pollen concentration recorded the increase of fruit size and pulp [13]. Fruit set in date palm trees also affected by the amount of pollen grains used in mechanical methods [17]. Therefore, the secret of better fruit lies in the fact that how effectively pollen powder reaches the female flowers using either of the methods. It is a likely that the male inflorescence strands remain in the female bunch for longer time in manually pollinated strands and therefore increases the chances of pollination for longer duration. In contrast, mechanical pollination can only pollinate the flowers, which are open at the time of pollination. Therefore, experiments of pollination with mechanical procedure at multiple times with varied pollen concentrations are required to optimise the best pollen concentration for better fruit quality and improved yield. 

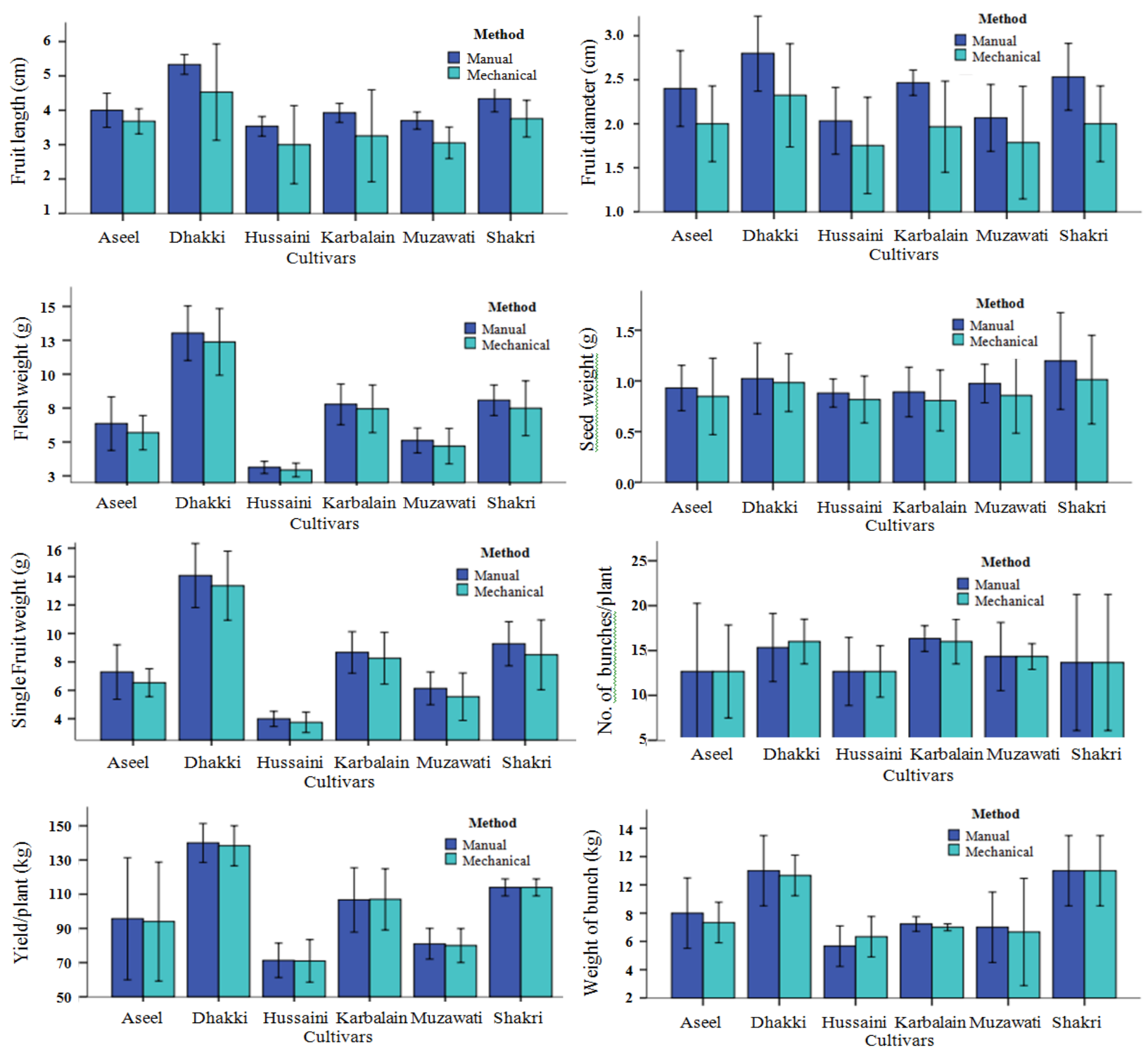

Figure 2. Effect of two pollination methods (Manual and Mechanical pollination) on the fruiting and vield of various Date balm cultivars

\section{Conclusion}

The study found a significant variation in fruit quality of the cultivars. Our results indicate a better production of cv. Dhakki and cv. Shakri in the agro climatic conditions of Khairpur district. Although, the fruit quality found to be better with the manual pollination method, the two pollination methods did not significantly affect the overall production of the dates. Further, experiments on mechanical pollination with varied concentration of pollen powder and a wide range of pollinating frequency recommended optimizing the mechanical pollination method for best fruit quality.

\section{Authors' contributions}

Conceived and designed the experiments: MM Rahman, Performed the experiments: MM Rahman \& M Hussain, Analyzed the data: M Hussain \& A Ahmad, Contributed 
materials/ analysis/ tools: S Lal \& M Ali, Wrote the paper: MM Rahman \& M Hussain.

\section{References}

1. Lemlem A, Alemayehu $M$ \& Endris $M$ (2018). Date Palm Production Practices and Constraints in the Value Chain in Afar Regional State, Ethiopia. Advances in Agri, pp 10.

2. Sakr MM, Abu Zeid IM, Hassan AE \& Hassan WM (2010). Identification of some date palm (Phoenix dactylifera L.) cultivars by fruit characters. Inter $J$ of $S c i$ and Tech 3(3): 338-343.

3. Iqbal $M$, Niamatullah $M$ \& Munir $M$ (2012). Effect of various Phoenix dactylifera males pollinizer on pomological traits and economical yield of cultivars Shakri, Zahidi and Dhakki. $J$ of Animal and Plant Sci 22(3): 376-383.

4. DejrouniA, Adel C, Ahmed S, Benmehaia R \& Baka M (2015). Evaluation of male palm used in pollination and the extent of its relationship with cultivars of date palm (Phoenix dactylifera L.) grown in region of QuedRigh, Algeria. Pak J of Bot 47(5): 2295-2300.

5. Abdul-Hamid AN (2000). Effect of time, rate and patterns of thinning, leaf bunch ratio and male type on Zaghloul date yield and quality. Arab Uni J of Agri Sci 8(1): 305-317.

6. Helail BM \&El-Kholey LA (2000). Effect of pollen source on palm fruiting and date quality of Hallawy and Khadrawy date palm. Annals of Agri Sci 38(1): 479-494.

7. Islam SE (2017). Evaluation of Date palm males types as pollinators for Zaghloul and Samany Date palm cvs. grown in Qalyubia Governorate. Middle East J Agri Res 6(4): 1049-1056.

8. Awad MA \& Al-Qureshi AD (2012). Partial fruit set failure phenomenon in 'Nabbut-Ali' and 'Sabbaka' date palm cultivars under hot arid climate as affected by pollinator type and pollination method. Scientia Horti 135: 157-163.

9. Soliman SS, AlebidiAI, Al-Saif AM, AlObeed RS \& Al-Bahelly AN (2017). Impact of pollination by pollen grain water suspension spray on yield and fruit quality of segae date palm cultivar (Phoenix dactylifera L.). Pak J of Bot 49(1): 119123.

10. Zaid A \& de Wet PF (2002). Pollination and bunch management in Date palm Cultivation, FAO Plant Production and Protection Paper No. 156. Rome: FAO.

11. IBM Corp (2010). IBM SPSS statistics for windows, version 20.0. Armonk, NY: IBM Corp.

12. Fowler L, Cohen L, Jarvis P (1998) Practical Statistics for Field Biology. $2^{\text {nd }}$ ed. Chichester: John Wiley \& Sons Ltd.

13. Samouni MTM, El-Salhy AM, Badawy IFM \& Ahmed EF(2016). Effect of pollination and thinning methods on yield and fruit quality of Saidy Date palms. Assiut J of Agri Sci 47(3): 92-103.

14. El-Mardi MO, Esechie H, Al-Kharousi LM \&Abdelbasit KM (2002). Effect of pollination method on changes in physical and chemical characteristics of date Fruit during development. Agri Sci 7(1): 21-27.

15. Al-Wusaibai NA, Ben Abdallah A, AlHusainai MS, Al-Salman H \& Elballaj M (2012). A comparative study between mechanical and manual pollination in two premier Saudi Arabian date palm cultivars. Indian J of Sci and Tech 5(4): 2487-2490.

16. El-Kassas SE \& Mahmoud HM (1986). The possibility of pollinating date palm by diluted pollen. Proc. 2nd Symp. Date Palm. King Faisal Univ, Al-Hassa, Saudi Arabia, pp 317-321.

17. Attalla AM, Warring MO \& Sharaan FA (1998). Suitable time of pollination of two Saudi Arabian date palm cultivars. Alexandria J of Agri Res 43(3): 203- 208. 